\title{
Radical cystectomy over the age of 75 is safe and increases survival
}

\author{
Stavros I Tyritzis ${ }^{1,3 *}$, loannis Anastasiou', Konstantinos G Stravodimos ${ }^{1}$, Aristeides Alevizopoulos ${ }^{1}$, Anastasios Kollias ${ }^{2}$, \\ Antonios Balangas ${ }^{2}$, loannis Katafigiotis ${ }^{1}$, loannis Leotsakos ${ }^{1}$, Dionysios Mitropoulos ${ }^{1}$ and \\ Constantinos A Constantinides ${ }^{1}$
}

\begin{abstract}
Background: Radical cystectomy (RC) is probably underused in elderly patients due to a potential increased postoperative complication risk, as reflected by their considerable comorbidities. Our objective was to estimate the overall complication rate and investigate a potential benefit to patients over the age of 75 subjected to RC in terms of disease-free survival.
\end{abstract}

Methods: A total of 81 patients, 61 men and 20 women, from two urological departments, with a mean age of $79.2 \pm 3.7$ years, participated in the study. The mean follow-up period was $2.6 \pm 1.6$ years. All patients underwent RC with pelvic lymphadenectomy. An ileal conduit, an orthotopic ileal neobladder and cutaneous ureterostomies were formed in $48.1 \%, 6.2 \%$ and $45.7 \%$ of the patients, respectively. The perioperative and 90 -day postoperative complications were recorded and classified according to the modified Clavien classification system. Survival plots were created based on the oncological outcome and several study parameters.

Results: The perioperative morbidity rate was 43.2\%; the 90-day morbidity rate was 37\%, while the 30-day, 90-day and overall mortality rates were $3.7 \%, 3.7 \%$ and $21 \%$, respectively. Overall mortality rates were recorded at the final year of data gathering (2009). Increased age, increased body mass index (BMI), longer hospitalization and age-adjusted Charlson comorbidity index (ACCI) more than six, were associated with greater hazard for 90-day morbidity. The cumulative mortality / metastasis-free rates for one, two, three and five years were $88.7 \%, 77.5 \%, 70.4 \%$, and 62.3\%, respectively. Tumour stage and positive nodes were prognostic predictors for oncological outcome.

Conclusions: RC in patients over 75 is justified and feasible, due to acceptable complication rates and high 5-year cancer-specific survival, which support an aggressive approach. Prospective studies are needed for the verification of the above results.

Keywords: Radical cystectomy, Octogenarians, Complications, Survival, Clavien classification system, Charlson comorbidity index

\section{Background}

Muscle-invasive bladder cancer incidence increases with age and peaks in the octogenarians [1,2]. Even though radical cystectomy $(\mathrm{RC})$ is the gold standard for this disease [3], it is underused and possibly inappropriately denied, because the majority of these patients are either unfit for surgery or have considerable comorbidities. This selection

\footnotetext{
* Correspondence: styritzis@med.uoa.gr

'Department of Urology, Athens University Medical School, LAIKO Hospital, Athens, Greece

${ }^{3}$ Department of Urology, Athens University Medical School, LAIKO Hospital, 17 Agiou Thoma str., Athens 11527, Greece

Full list of author information is available at the end of the article
}

bias might preclude a potential effective management in the older patients [4]. The above argument is further strengthened by a recent report concluding that bladdersparing protocols in octogenarians with $>\mathrm{pT} 2$ disease and American Society of Anesthesiologists (ASA) score 3-4 has a very bad prognosis [5].

Increased surgical experience and improvements in surgical techniques are constantly expanding the indications for aggressive treatment. This fact provided the rationale for our study, which attempted to investigate the feasibility of $\mathrm{RC}$ in these high-risk patients and establish a potential benefit on cancer-specific survival in the long term.

\section{Biomed Central}

(C) 2012 Tyritzis et al.; licensee BioMed Central Ltd. This is an Open Access article distributed under the terms of the Creative Commons Attribution License (http://creativecommons.org/licenses/by/2.0), which permits unrestricted use, distribution, and reproduction in any medium, provided the original work is properly cited. 


\section{Methods}

We reviewed the files of 81 patients, 61 men and 20 women, with a mean age of 79.2 years $(\mathrm{SD}=3.7$ years) (range 75-95 years). All patients, after providing informed consent, underwent RC and pelvic lymphadenectomy from 2000 through 2009. Ethical approval was not required due to the retrospective nature of the study, as stated by our institutions scientific committee. The clinical and demographic characteristics of the patients are shown in Table 1. The indications for $\mathrm{RC}$ were muscle invasive disease, non muscle invasive disease refractory to intravesical chemotherapy and/or immunotherapy and palliation treatment for uncontrolled haemorrhage (in 11 out of 81 patients). No patient had distant metastasis at the time of the operation. No patient received neo-adjuvant chemotherapy or radiotherapy, while $12(14.8 \%)$ and 3 patients (3.7\%) received adjuvant chemotherapy and external beam radiotherapy, respectively.

Perioperative complications were defined as complications occurring within the first 10 postoperative days.

Table 1 Demographic and clinical characteristics of the study group

\begin{tabular}{|c|c|c|}
\hline & $\mathbf{N}$ & $\%$ \\
\hline \multicolumn{3}{|l|}{ Gender } \\
\hline Men & 61 & 75.3 \\
\hline Women & 20 & 24.7 \\
\hline Age (years), mean (SD) & \multicolumn{2}{|c|}{$79.2(3.7)$} \\
\hline \multicolumn{3}{|l|}{ Age (years)* } \\
\hline$<77$ & 23 & 28.4 \\
\hline $77-80$ & 31 & 38.3 \\
\hline$>80$ & 27 & 33.3 \\
\hline BMI, mean (SD) & \multicolumn{2}{|c|}{$25.5(3.2)$} \\
\hline \multicolumn{3}{|l|}{ Urinary diversion } \\
\hline Ileal conduit & 39 & 48.1 \\
\hline S-pouch & 5 & 6.2 \\
\hline Cutaneous ureterostomy & 37 & 45.7 \\
\hline
\end{tabular}

\begin{tabular}{lll}
\hline pTis & 12 & 14.8 \\
\hline pT1 to pT2b & 28 & 34.6 \\
\hline pT3a to pT3b & 29 & 35.8 \\
\hline pT4a to pT4b & 12 & 14.8 \\
\hline
\end{tabular}

\begin{tabular}{lll}
\hline Nodes (TNM system) & & \\
\hline 0 & 60 & 74.1 \\
\hline $1-2$ & 21 & 25.9 \\
\hline Hospital stay (days), mean (SD) & & $13.0(7.3)$ \\
\hline Charlson score & & \\
\hline$\leq 6$ & 69 & 85.2 \\
\hline$>6$ & 12 & 14.8 \\
\hline
\end{tabular}

*categorized according to tertiles.

BMI: Body mass index.

SD: Standard deviation. 90-day morbidity and mortality were also recorded. The Martin criteria for standardized reporting of complications were used [6] (Table 2). The complications were classified according to the modified Clavien classification system [7] (Table 3). Follow-up of the patients was performed by scheduled hospital visits and telephone interviews.

\section{Statistical analysis}

Quantitative variables are expressed as mean $( \pm \mathrm{SD})$ or as median values (interquartile range). Qualitative variables are expressed as absolute and relative frequencies. Life table analyses were used to calculate cumulative survival rate (standard errors) for specific time intervals. The prognostic value of each variable was first assessed by univariate Cox regression analysis. Variables that showed significant association with the outcome were included in the multivariate Cox proportional-hazard model in a stepwise method, in order to determine the independent predictors for morbidity and oncological outcome. The assumption of proportional hazards was evaluated by testing for interaction with a continuous time variable. Kaplan - Meier survival estimates for soft and hard events were graphed over the follow-up period. All reported

\section{Table 2 Martin criteria for standardized complication} reporting

\begin{tabular}{|c|c|}
\hline Criteria & Requirement \\
\hline $\begin{array}{l}\text { Method of accruing } \\
\text { data defined }\end{array}$ & $\begin{array}{l}\text { Prospective or retrospective accrual of } \\
\text { data are indicated. }\end{array}$ \\
\hline \multirow[t]{2}{*}{$\begin{array}{l}\text { Duration of follow-up } \\
\text { indicated }\end{array}$} & $\begin{array}{l}\text { Report clarifies the time period of } \\
\text { postoperative accrual }\end{array}$ \\
\hline & $\begin{array}{l}\text { of complications such as } 30 \text { days or } \\
\text { same hospitalization. }\end{array}$ \\
\hline \multirow[t]{2}{*}{$\begin{array}{l}\text { Outpatient information } \\
\text { included }\end{array}$} & $\begin{array}{l}\text { Study indicates that complications } \\
\text { first identified following }\end{array}$ \\
\hline & discharge are included in the analysis. \\
\hline $\begin{array}{l}\text { Definitions of complications } \\
\text { provided }\end{array}$ & $\begin{array}{l}\text { Article defines at least one } \\
\text { complication with specific inclusion } \\
\text { criteria. }\end{array}$ \\
\hline \multirow[t]{2}{*}{$\begin{array}{l}\text { Mortality rate and causes } \\
\text { of death listed }\end{array}$} & $\begin{array}{l}\text { The number of patients who died } \\
\text { in the postoperative period of study }\end{array}$ \\
\hline & $\begin{array}{l}\text { are recorded together with cause } \\
\text { of death. }\end{array}$ \\
\hline \multirow[t]{2}{*}{$\begin{array}{l}\text { Morbidity rate and total } \\
\text { complications indicated }\end{array}$} & $\begin{array}{l}\text { The number of patients with any } \\
\text { complication and the total number }\end{array}$ \\
\hline & of complications are recorded. \\
\hline \multicolumn{2}{|c|}{$\begin{array}{l}\text { Procedure-specific complications } \\
\text { included }\end{array}$} \\
\hline \multirow[t]{2}{*}{ Severity grade utilized } & $\begin{array}{l}\text { Any grading system designed to } \\
\text { clarify severity of complications }\end{array}$ \\
\hline & $\begin{array}{l}\text { including "major and minor" } \\
\text { is reported. }\end{array}$ \\
\hline Length-of-stay data & $\begin{array}{l}\text { Median or mean length of stay } \\
\text { indicated in the study. }\end{array}$ \\
\hline $\begin{array}{l}\text { Risk factors included in } \\
\text { the analysis }\end{array}$ & $\begin{array}{l}\text { Evidence of risk stratification and } \\
\text { method used indicated by study. }\end{array}$ \\
\hline
\end{tabular}


Table 3 Clavien classification of perioperative and 90-day morbidity and mortality

\begin{tabular}{|c|c|c|c|c|c|c|}
\hline \multirow{3}{*}{$\begin{array}{l}\text { CLAVIEN grade } \\
\text { No complication }\end{array}$} & & \multirow{2}{*}{$\begin{array}{c}\mathrm{N} \\
29\end{array}$} & \multicolumn{2}{|l|}{$\%$} & \multirow[t]{2}{*}{$\mathrm{N}$} & \multirow[t]{2}{*}{$\%$} \\
\hline & & & 35.8 & & & \\
\hline & $\begin{array}{l}\text { Perioperative morbidity } \\
\text { (0-10d) }\end{array}$ & 35 & 43.2 & 90-day morbidity & 30 & 37 \\
\hline 1 & & 11 & 13.6 & & 15 & 18.6 \\
\hline \multirow{5}{*}{$\begin{array}{l}\text { Any deviation from the normal postoperative course } \\
\text { without the need for pharmacological treatment or } \\
\text { surgical, endoscopic, and radiological interventions. } \\
\text { Allowed therapeutic regimens are: drugs as antiemetics, } \\
\text { antipyretics, analgetics, diuretics, electrolytes, and } \\
\text { physiotherapy. This grade also includes wound infections } \\
\text { opened at the bedside. }\end{array}$} & Hyperemesis & 1 & 1.2 & Pneumonia & 2 & 2.4 \\
\hline & Fever & 7 & 8.4 & Psoas abscess & 1 & 1.2 \\
\hline & lleus & 1 & 1.2 & Wound infection & 11 & 13.6 \\
\hline & Pneumonia & 1 & 1.2 & Lympocele & 1 & 1.2 \\
\hline & Urine leakage & 1 & 1.2 & & & \\
\hline 2 & & 22 & 27.2 & & 4 & 4.8 \\
\hline \multirow{2}{*}{$\begin{array}{l}\text { Requiring pharmacological treatment with drugs } \\
\text { other than such allowed for grade I complications. } \\
\text { Blood transfusions and total parenteral nutrition } \\
\text { are also included. }\end{array}$} & Blood transfusion & 21 & 25.9 & Wound dehiscense & 1 & 1.2 \\
\hline & UTI & 1 & 1.2 & UTI & 3 & 3.6 \\
\hline 3 & & 1 & 1.2 & & 6 & 7.2 \\
\hline \multicolumn{7}{|l|}{ Requiring surgical, endoscopic or radiological intervention } \\
\hline $3 a$ & - & - & 0 & & 2 & 2.4 \\
\hline \multirow[t]{2}{*}{ Intervention not under general anesthesia } & - & - & 0 & Cardiac arrythmia-pacemaker & 1 & 1.2 \\
\hline & & & & Obstructive nephropathy & 1 & 1.2 \\
\hline $3 \mathbf{b}$ & & 1 & 1.2 & & 4 & 4.8 \\
\hline \multirow[t]{3}{*}{ Intervention under general anesthesia } & Rectal injury, re-operation, colostomy & 1 & 1.2 & Evisceration, re-operation & 1 & 1.2 \\
\hline & & & & Stricture ileus, re-operation & 2 & 2.4 \\
\hline & & & & Incisional hernia & 1 & 1.2 \\
\hline 4 & & 1 & 1.2 & & 2 & 2.4 \\
\hline \multirow[t]{2}{*}{$\begin{array}{l}\text { Life-threatening complication (including CNS complications) } \\
\text { requiring IC/ICU management }\end{array}$} & Sepsis & 1 & 1.2 & Myocardial Infarction & 1 & 1.2 \\
\hline & & & & Sepsis & 1 & 1.2 \\
\hline 5 & - & - & 0 & & 3 & 3.7 \\
\hline \multirow[t]{4}{*}{ Death of a patient } & & & & Death & 3 & 3.7 \\
\hline & & & & 30-day (sepsis, pneumonia) & 2 & 2.4 \\
\hline & & & & 60-day (evisceration, re-operation & 1 & 1.2 \\
\hline & & & & 90-day & 0 & 0 \\
\hline
\end{tabular}

$\mathrm{p}$ values are two-tailed. Statistical significance was set at $\mathrm{p}<0.05$ and analyses were conducted using the SPSS statistical software (version 17.0).

\section{Results}

The mean follow-up period was $2.6 \pm 1.6$ years with median equal to 2.4 years (interquartile range from 1.2 to 3.9 years). During the follow-up period, the perioperative morbidity rate was $43.2 \%(\mathrm{~N}=35), 90$-day morbidity rate was $35.8 \%(\mathrm{~N}=29)$, the perioperative and overall mortality rates were $3.7 \%$ and $21.0 \%$, respectively, while 6 patients had metastasis $(7.4 \%)$. In salvage $\mathrm{RC}$, perioperative morbidity rate was $45.4 \%$, 90-day morbidity rate reached $36.4 \%$, while perioperative mortality was $9 \%$. Positive nodes were found in $25.9 \%$ of the patients. The mean length of hospitalization was $13.0 \pm 7.3$ days and $14.8 \%$ of the patients had an age-adjusted Charlson comorbidity index (ACCI) more than six. Table 4 presents the results of univariate analysis for the association of study parameters with perioperative morbidity. Perioperative morbidity rate was not significantly different when adjusted to the clinical and demographic characteristics of the patients. Univariate Cox 
Table 4 Demographic and clinical characteristics of the study group associated with perioperative morbidity

\begin{tabular}{|c|c|c|c|c|c|}
\hline & \multicolumn{4}{|c|}{ Perioperative morbidity (10 days) } & \multirow{3}{*}{$\begin{array}{l}\mathrm{Px}^{2} \\
\text { test }\end{array}$} \\
\hline & \multicolumn{2}{|c|}{ No } & \multicolumn{2}{|c|}{ Yes } & \\
\hline & $\mathrm{N}$ & $\%$ & $\mathrm{~N}$ & $\%$ & \\
\hline \multicolumn{6}{|l|}{ Gender } \\
\hline Male & 36 & 59.0 & 25 & 41.0 & 0.752 \\
\hline Female & 11 & 55.0 & 9 & 45.0 & \\
\hline Age (years) , mean (SD) & \multicolumn{2}{|c|}{$79.3(4.0)$} & \multicolumn{2}{|c|}{$78.9(3.2)$} & $0.650^{* *}$ \\
\hline \multicolumn{6}{|l|}{ Age (years) } \\
\hline$<77$ & 14 & 60.9 & 9 & 39.1 & 0.895 \\
\hline $77-80$ & 17 & 54.8 & 14 & 45.2 & \\
\hline$>80$ & 16 & 59.3 & 11 & 40.7 & \\
\hline BMI, mean (SD) & \multicolumn{2}{|c|}{$25.6(2.9)$} & \multicolumn{2}{|c|}{$25.5(3.7)$} & $0.873^{* *}$ \\
\hline \multicolumn{6}{|l|}{ Urinary diversion } \\
\hline Ileal conduit & 22 & 56.4 & 17 & 43.6 & $0.724^{*}$ \\
\hline S-pouch & 4 & 80.0 & 1 & 20.0 & \\
\hline Cutaneous ureterostomy & 21 & 56.8 & 16 & 43.2 & \\
\hline \multicolumn{6}{|l|}{ pT (TNM system) } \\
\hline pTis & 3 & 25.0 & 9 & 75.0 & 0.070 \\
\hline pT1 to pT2b & 17 & 60.7 & 11 & 39.3 & \\
\hline pT3a to pT3b & 18 & 62.1 & 11 & 37.9 & \\
\hline pT4a to pT4b & 9 & 75.0 & 3 & 25.0 & \\
\hline \multicolumn{6}{|l|}{ Nodes (TNM system) } \\
\hline 0 & 34 & 56.7 & 26 & 43.3 & 0.675 \\
\hline $1-2$ & 13 & 61.9 & 8 & 38.1 & \\
\hline Hospital stay, mean (SD) & \multicolumn{2}{|c|}{$13.7(8.4)$} & \multicolumn{2}{|c|}{$12.1(5.4)$} & $0.334^{* *}$ \\
\hline \multicolumn{6}{|l|}{ Charlson score } \\
\hline$\leq 6$ & 39 & 56.5 & 30 & 43.5 & 0.511 \\
\hline$>6$ & 8 & 66.7 & 4 & 33.3 & \\
\hline
\end{tabular}

regression analysis for 90-day morbidity (Table 5) revealed that increased age, increased body mass index (BMI), hospital stay and ACCI more than six, were associated with greater hazard for 90-day morbidity. When multiple Cox regression analysis with stepwise-forward approach was applied (Table 6), it was found that age, BMI, hospital stay and ACCI were independently associated with morbidity. Specifically, for one day increase in hospital stay, the morbidity hazard increases by $6 \%$, while for one unit increase in BMI, the morbidity hazard increases by $18 \%$. Furthermore, patients aged 77 to 80 years and those aged more than 80 years had greater morbidity hazard compared to those aged less than 77 years with adjusted hazard ratios equal to 4.92 and 5.86, respectively. Additionally, subjects with ACCI more than six had 2.51 times greater morbidity hazard compared to those with ACCI equal or less than six. Kaplan Meier morbidity estimations according to ACCI are presented in Figure 1.
Table 5 Univariate and multiple Cox proportional hazards models for the prediction of 90-day morbidity

\begin{tabular}{|c|c|c|c|c|}
\hline & $\begin{array}{c}\text { Crude } \\
\text { HR }(95 \% \text { Cl }) \ddagger\end{array}$ & $\mathbf{P}$ & $\begin{array}{c}\text { Adjusted } \\
\text { HR }(95 \% \mathrm{Cl})\end{array}$ & $\mathbf{P}$ \\
\hline \multicolumn{5}{|l|}{ Gender } \\
\hline Male & $1.00^{*}$ & & & \\
\hline Female & $0.98(0.42-2.28)$ & 0.955 & & \\
\hline $\begin{array}{c}\text { Age (years) } \\
\text { mean } \pm \text { SD }\end{array}$ & $1.08(0.99-1.17)$ & 0.079 & & \\
\hline \multicolumn{5}{|l|}{ Age (years) } \\
\hline$<77$ & $1.00^{*}$ & & $1.00^{*}$ & \\
\hline $77-80$ & $4.12(1.18-14.33)$ & 0.026 & $4.92(1.35-17.95)$ & 0.016 \\
\hline$>80$ & $4.04(1.14-14.31)$ & 0.031 & $5.86(1.47-23.42)$ & 0.012 \\
\hline BMI, mean \pm SD & $1.15(1.04-1.27)$ & 0.008 & $1.18(1.04-1.34)$ & 0.011 \\
\hline \multicolumn{5}{|l|}{ Urinary diversion } \\
\hline Ileal conduit & $1.00^{*}$ & & & \\
\hline S-pouch & ** & & & \\
\hline $\begin{array}{l}\text { Cutaneous } \\
\text { ureterostomy }\end{array}$ & $1.18(0.57-2.44)$ & 0.658 & & \\
\hline \multicolumn{5}{|l|}{ pT (TNM system) } \\
\hline pTis & $1.00^{*}$ & & & \\
\hline pT1 to pT2b & $0.51(0.18-1.42)$ & 0.197 & & \\
\hline pT3a to pT3b & $0.62(0.23-1.72)$ & 0.362 & & \\
\hline pT4a to pT4b & $0.56(0.16-2)$ & 0.377 & & \\
\hline
\end{tabular}

\begin{tabular}{|c|c|c|c|c|}
\hline Nodes (TNM sy & & & & \\
\hline 0 & $1.00^{*}$ & & & \\
\hline $1-2$ & $1.2(0.53-2.7)$ & 0.665 & & \\
\hline $\begin{array}{c}\text { Hospital stay, } \\
\text { mean } \pm \text { SD }\end{array}$ & $1.05(1.02-1.09)$ & 0.002 & $1.06(1.02-1.09)$ & 0.002 \\
\hline \multicolumn{5}{|l|}{ Charlson score } \\
\hline$\leq 6$ & $1.00^{*}$ & & $1.00^{*}$ & \\
\hline$>6$ & $2.43(1.03-5.7)$ & 0.042 & $2.51(1.06-5.94)$ & 0.037 \\
\hline
\end{tabular}

The cumulative mortality / metastasis-free rates for one, two, three and five years were $88.7 \%$ [Standard Error $(\mathrm{SE})=3.6 \%], 77.5 \%(\mathrm{SE}=4.8 \%), 70.4 \%(\mathrm{SE}=5.5 \%)$ and $62.3 \%(\mathrm{SE}=7.3 \%)$, respectively. Both univariate and multiple analysis concerning death or metastasis (Table 5) revealed that tumour stage and nodes were prognostic predictors for oncological outcome. Specifically, as resulted from multiple analysis, patients with tumour stage pT4a to pT4b had 9.19 times greater hazard for death or metastasis compared to those with in situ tumours. Moreover, patients with one or two positive nodes had 2.4 times greater hazard for death or metastasis. Kaplan Meier estimates for death or metastasis according to tumour stage and nodes are presented in Figures 2 and 3, respectively.

\section{Discussion}

Octogenarians are per se, a high-risk group, due to their comorbidities. Using the age-adjusted Charlson comorbidity 
Table 6 Univariate and multiple Cox proportional hazards models for the prediction of death/metastasis

\begin{tabular}{|c|c|c|c|c|}
\hline & $\begin{array}{c}\text { Crude } \\
\text { HR }(95 \% \mathrm{Cl})\end{array}$ & $\mathbf{P}$ & $\begin{array}{c}\text { Adjusted } \\
\text { HR }(95 \% \mathrm{Cl})\end{array}$ & $\mathbf{P}$ \\
\hline \multicolumn{5}{|l|}{ Gender } \\
\hline Male & $1.00^{*}$ & & & \\
\hline Female & $0.41(0.12-1.4)$ & 0.155 & & \\
\hline $\begin{array}{l}\text { Age (years), } \\
\text { mean } \pm \text { SD }\end{array}$ & $1(0.89-1.13)$ & 0.976 & & \\
\hline \multicolumn{5}{|l|}{ Age (years) } \\
\hline$<77$ & $1.00^{*}$ & & & \\
\hline $77-80$ & $1.57(0.57-4.34)$ & 0.382 & & \\
\hline$>80$ & $1.06(0.36-3.17)$ & 0.910 & & \\
\hline BMI, mean \pm SD & $0.96(0.84-1.1)$ & 0.563 & & \\
\hline \multicolumn{5}{|l|}{ Urinary diversion } \\
\hline Ileal conduit & $1.00^{*}$ & 0.997 & & \\
\hline S-pouch & $* *$ & & & \\
\hline $\begin{array}{l}\text { Cutaneous } \\
\text { ureterostomy }\end{array}$ & $1.03(0.45-2.36)$ & 0.944 & & \\
\hline \multicolumn{5}{|l|}{ pT (TNM system) } \\
\hline pTis & $1.00^{*}$ & & $1.00^{*}$ & \\
\hline pT1 to pT2b & $3.11(0.37-25.88)$ & 0.293 & $2.87(0.35-23.9)$ & 0.329 \\
\hline pT3a to pT3b & $5.5(0.7-43.04)$ & 0.105 & $5.99(0.76-46.95)$ & 0.088 \\
\hline pT4a to pT4b & $9.11(1.09-75.81)$ & 0.041 & $9.19(1.10-76.58)$ & 0.040 \\
\hline \multicolumn{5}{|c|}{ Nodes (TNM system) } \\
\hline 0 & $1.00^{*}$ & & $1.00^{*}$ & \\
\hline $1-2$ & $2.52(1.10-5.75)$ & 0.028 & $2.4(1.05-5.49)$ & 0.039 \\
\hline $\begin{array}{c}\text { Hospital stay. } \\
\text { mean } \pm \text { SD }\end{array}$ & $0.99(0.93-1.06)$ & 0.777 & & \\
\hline
\end{tabular}

index, for each decade over the age of 40 years, one point is added to the total score, a fact that reflects the significance of age in the performance status of a patient [8]. Koppie et al recently suggested the association between ACCI and the clinical and oncological outcome after a RC [9]. Other authors also reported that postoperative morbidity is higher in patients with higher ASA score and more than 2 comorbidities [10]. The same conclusion was reached by a collaborative review, which however, stated that age alone does not preclude RC in the elderly [11].

Our results of perioperative mortality and 90-day morbidity are comparable to those of the above mentioned reviews, which range between $0-11 \%$ and as high as $64 \%$ [11], respectively, support the notion of an aggressive treatment offered to octogenarians. The 90-day instead of the 30-day or the 60-day morbidity was selected because it is already established as a more potent and realistic description tool of the postoperative risks of the RC morbidity, as several reports are suggesting $[11,12]$. The 90-day morbidity along with the use of the Clavien classification system, give a distinct advantage in our study in terms of complication reporting quality [11-13].

The incidence of wound complications was surprisingly high in our series (11\%) and it could be attributed to poor healing capacity and poor patient hygiene. In order to avoid this kind of complication, we now routinely use tension sutures along with Nylon sutures or clips for wound closure at the end of the operation, which are removed approximately one month later.

The complication rates did not vary between salvage and primary RC. The main difference was that perioperative mortality was significantly higher in the salvage RC (9\% vs. $3.7 \%$ ), which was somewhat expected, due to the nature of

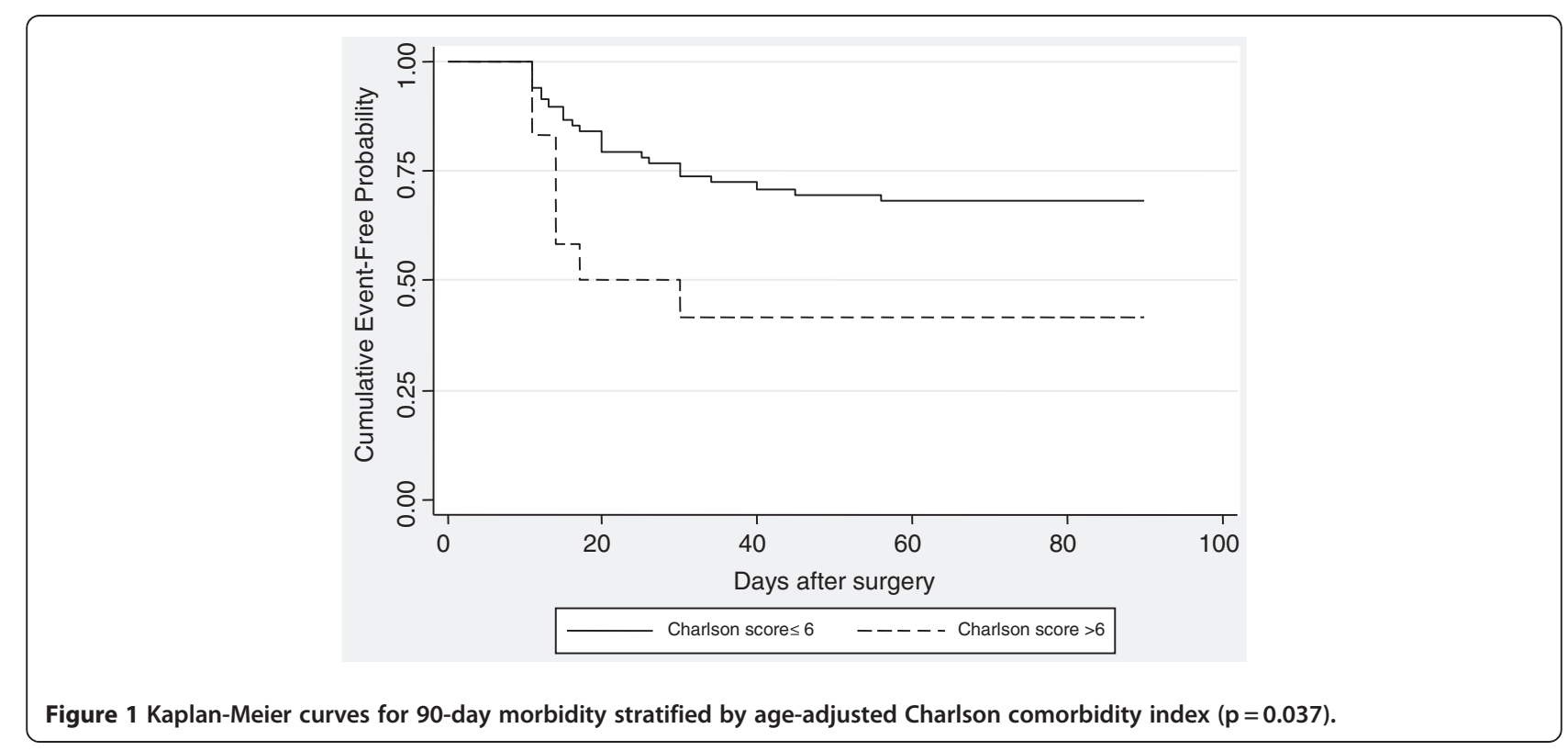




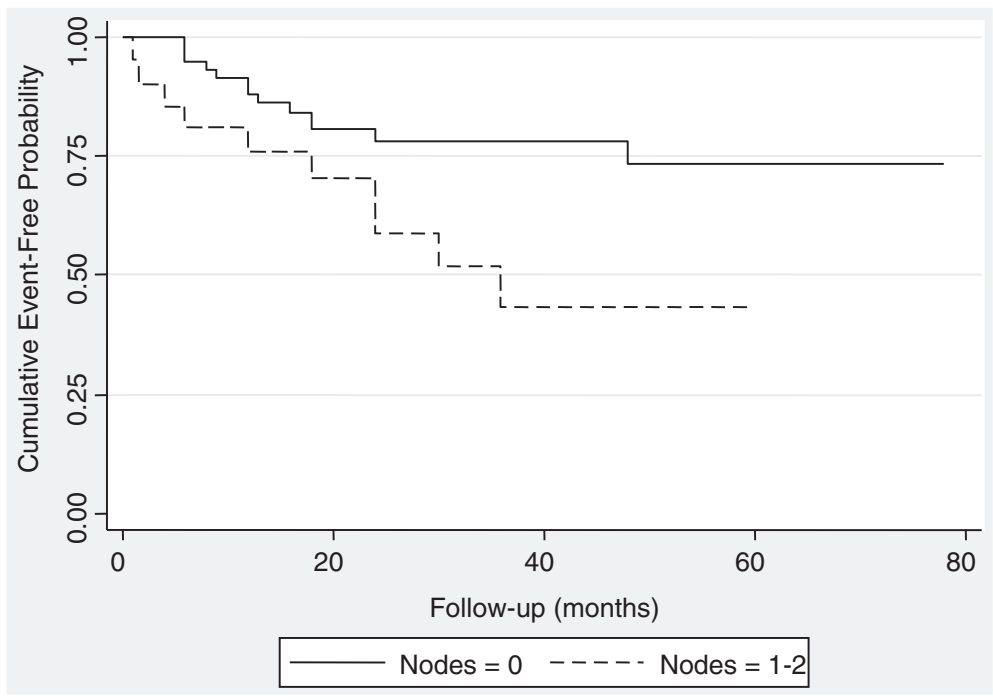

Figure 2 Kaplan-Meier curves for event-free probability stratified by nodal status. $(p=0.039)$.

the disease and the performance status of the patient at the time of the operation. The above observation is in accordance to other authors [14,15]. Furthermore, obesity and longer hospital stay have been identified as risk factors for higher postoperative morbidity.

The selected type of urinary diversion does not seem to alter the morbidity/mortality outcome, as shown in other studies as well $[11,16]$. It is however important to notice, that high-volume centers, performing $>50 \mathrm{RC}$ 's per year should be involved in these cases, because the surgical experience in these centers is more advanced and is associated with improved postoperative outcomes, including decreased mortality, shorter length of hospital stay and lower rehospitalization rates [11,17].

Cancer-specific survival is another major concern when the decision to perform $\mathrm{RC}$ in an octogenarian should be taken, as the reported results are rather controversial. Two retrospective studies, reviewing a total of approximately 1120 patients have reported unfavourable oncological outcomes in elderly patients $[18,19]$. In the first study, the 5 -year was $28.1 \%$, while in the second the 3 -year and 7 -year cancer-specific survival rates were between $70 \%$ and $55.2 \%$, respectively. On the other hand, Chamie et al and Hollenbeck et al provided some evidence that RC has

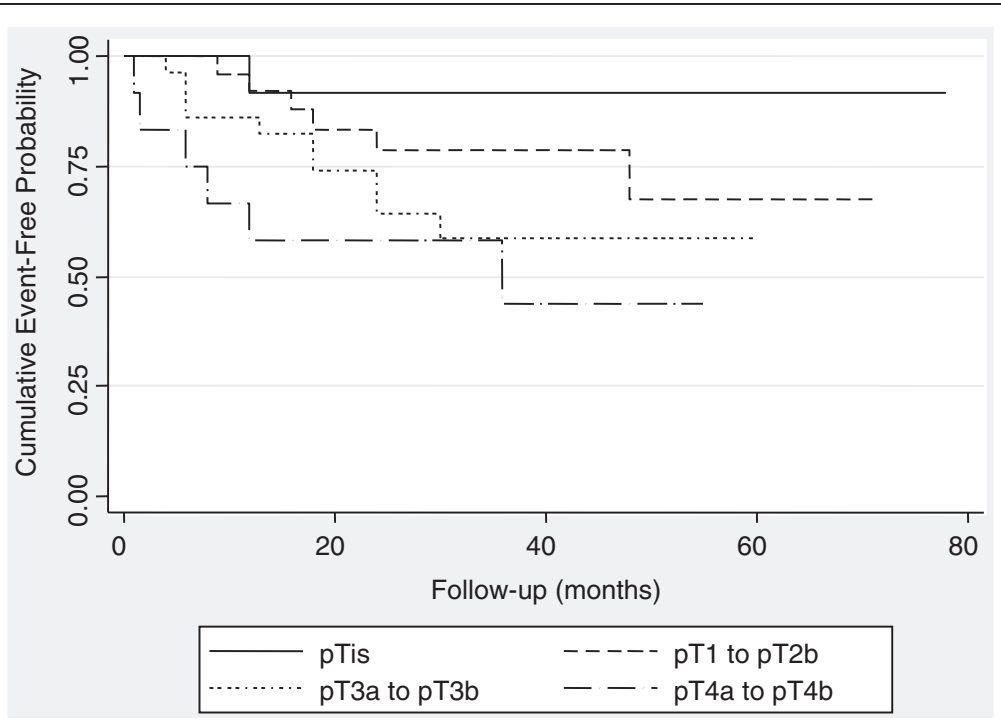

Figure 3 Kaplan-Meier curves for event-free probability stratified by tumour stage. $(p T 1-p T 2 b: p=0.329, p T 3: p=0.08, p T 4: p=0.04)$. 
some benefit in the elderly, when compared to watchful waiting, or radiotherapy and chemotherapy $[4,20]$. Chamie and colleaques also stated that pelvic lymphadenectomy should be performed in order for RC to show any survival advantage in the octogenarians [20]. Based on our results, we advocate RC and lymphadenectomy in the elderly patients, since the 5-year survival rate in our series was significantly high (62.3\%) and tumour stage and node status were prognostic predictors for the oncological outcome. Clinical tumour stage and grade remain the best predictors of cancer specific survival [21]. Therefore, it is imperative for the $\mathrm{RC}$ candidates to undergo a meticulous clinical and imaging examination.

\section{Conclusions}

Age should not hamper RC, particularly when it takes place in specialized, high-volume centers. The reported complication rates of this particular group of patients, especially when standardized with validated methodologies, are acceptable. Strict selection of non obese patients, with non metastatic disease and an ACCI less than six, may result in a better postoperative outcome.

\section{Competing interests}

The authors declare that they have no competing interests.

\section{Authors' contributions}

IA performed surgical procedures, participated in the study concept and design and critically revised the manuscript. SIT conceived the study, performed statistical analysis, drafted the manuscript, analyzed and interpreted the data. KGS performed surgical procedures, assisted in the study concept and design and revised the manuscript. AA participated in the acquisition of data. AK performed surgical procedures and provided patient data. AB participated in the acquisition of data. VM participated in the acquisition of data. DM performed surgical procedures, assisted in the study concept and design and revised the manuscript. CAC performed surgical procedures, assisted in the study concept and design and revised the manuscript. All authors read and approved the final manuscript.

\section{Author details}

'Department of Urology, Athens University Medical School, LAIKO Hospital, Athens, Greece. ${ }^{2}$ Department of Urology, Ammerland Clinics, Westerstede, Germany. ${ }^{3}$ Department of Urology, Athens University Medical School, LAIKO Hospital, 17 Agiou Thoma str., Athens, 11527, Greece.

Received: 22 November 2011 Accepted: 30 April 2012

Published: 30 April 2012

\section{References}

1. Jemal $A$, Clegg $L X$, Ward $E$, et al: Annual report to the nation on the status of cancer, 1975-2001, with a special feature regarding survival. Cancer 2004, 101:3-27.

2. Clark PE, Stein JP, Groshen SG, et al: Radical cystectomy in the elderly: comparison of clinical outcomes between younger and older patients. Cancer 2005, 104:36-43.

3. Stenzl A, Cowan NC, De Santis M, et al: The updated EAU guidelines on muscle-invasive and metastatic bladder cancer. Eur Urol 2009, 55:815-825.

4. Hollenbeck BK, Miller DC, Taub D, et al: Aggressive treatment for bladder cancer is associated with improved overall survival among patients 80 years old or older. Urology 2004, 64:292-297.

5. Wehrberger $C$, Berger I, Marszalek $M$, et al: Bladder preservation in octogenarians with invasive bladder cancer. Urology 2010, 75:370-375.

6. Martin RC 2nd, Brennan MF, Jaques DP: Quality of complication reporting in the surgical literature. Ann Surg 2002, 235:803-813.
7. Dindo D, Demartines N, Clavien PA: Classification of surgical complications. A new proposal with evaluation in a cohort of 6336 patients and results of a survey. Ann Surg 2004, 240:205-213.

8. Hall WH, Ramachandran R, Narayan S, Jani AB, Vijayakumar S: An electronic application for rapidly calculating Charlson comorbidity score. $B M C$ Cancer 2004, 4:94.

9. Koppie TM, Serio AM, Vickers AJ, et al: Age-adjusted Charlson comorbidity score is associated with treatment decisions and clinical outcomes for patients undergoing radical cystectomy for bladder cancer. Cancer 2008 112:2384-2392.

10. Boström PJ, Kössi J, Laato M, Nurmi M: Risk factors for mortality and morbidity related to radical cystectomy. BJU Int 2009, 103:191-196.

11. Froehner M, Brausi MA, Herr HW, Muto G, Studer UE: Complications following radical cystectomy for bladder cancer in the elderly. Eur Urol 2009, 56:443-454.

12. Shabsigh A, Korets R, Vora KC, et al: Defining early morbidity of radical cystectomy for patients with bladder cancer using a standardized reporting methodology. Eur Urol 2009, 55:164-176.

13. Chahal R, Sundaram SK, Iddenden R, Forman DF, Weston PMT, Harrison SCW: A study of the morbidity, mortality and long-term survival following radical cystectomy and radical radiotherapy in the treatment of invasive bladder cancer in Yorkshire. Eur Urol 2003, 43:246-257.

14. Crawford ED, Skinner DG: Salvage cystectomy after irradiation failure. $J$ Urol 1980, 123:32-34

15. Smith JA Jr, Whitmore WF Jr: Salvage cystectomy for bladder cancer after failure of definitive irradiation. J Urol 1981, 125:643-645.

16. Sogni $F$, Brausi M, Frea B, et al: Morbidity and quality of life in elderly patients receiving ileal conduit or orthotopic neobladder after radical cystectomy for invasive bladder cancer. Urology 2008, 71:919-923.

17. Barbieri CE, Lee $B$, Cookson MS, et al: Association of procedure volume with radical cystectomy outcomes in a nationwide database. J Urol 2007, 178:1418-1421.

18. Nielsen ME, Shariat SF, Karakiewicz Pl, et al: Bladder Cancer Research Consortium (BCRC). Advanced age is associated with poorer bladder cancer-specific survival in patients treated with radical cystectomy. Eur Urol 2007, 5:699-706.

19. Resorlu B, Beduk Y, Baltaci S, Ergun G, Talas H: The prognostic significance of advanced age in patients with bladder cancer treated with radical cystectomy. BJU Int 2009, 103:480-483.

20. Chamie K, Hu B, Devere White RW, Ellison LM: Cystectomy in the elderly: does the survival benefit in younger patients translate to the octogenarians? BJU Int 2008, 102:284-290.

21. Thrasher JB, Frazier HA, Robertson JE, Dodge RK, Paulson DF: Clinical variables which serve as predictors of cancer-specific survival among patients treated with radical cystectomy for transitional cell carcinoma of the bladder and prostate. Cancer 1994, 73:1708-1715.

doi:10.1186/1471-2318-12-18

Cite this article as: Tyritzis et al:: Radical cystectomy over the age of 75 is safe and increases survival. BMC Geriatrics 2012 12:18.

\section{Submit your next manuscript to BioMed Central and take full advantage of:}

- Convenient online submission

- Thorough peer review

- No space constraints or color figure charges

- Immediate publication on acceptance

- Inclusion in PubMed, CAS, Scopus and Google Scholar

- Research which is freely available for redistribution 